\title{
PENERAPAN SISTEM INFORMASI TRACER STUDY PADA UNIVERSITAS MUHAMMADIYAH KOTABUMI
}

\author{
Muhammad Adie Syaputra ${ }^{1}$, Irma Fatima ${ }^{2}$ \\ m4adie@gmail.com ${ }^{1}$,irma.fatimah16@gmail.com ${ }^{2}$
}

STMIK Dharmawacana Metro

\begin{abstract}
Tracer Study is research on the situation of alumni that aims to get a lot of information from graduates / alumni to improve the quality of graduates. Tracking alumni information that can be used as input and evaluation for improving learning and the competencies of graduates. Information in the form of activities / activities of the graduates / alumni after taking education at UMKO, both in the waiting period or having activities in the work world. Computerized tracer studies online in tracking alumni can easily list the desired alumni that can be directly provided by graduates / alumni, where the system built can record graduates / alumni based on graduation years, cometensi fields, number of graduates, job profiles depicted in the form percentage, graph or diagram. Software development uses OOSE method with stages: (1) Requirement Engineering, (2) Object Oriented Design, (3) Implementation or Coding, (4) Testin. The tracking process using an integrated system is able to connect and store all graduate information in 1 (one) media, so that it can provide information to anyone who needs it. In addition, the data entered directly by the alumni so that the data level is more accurate, so that it can provide input to UMKO to improve the quality of graduates.
\end{abstract}

Keywords: Tracer Study, Alumni, OOSE, Tracking

\begin{abstract}
Abstrak: Tracer Study adalah penelitian mengenai situasi alumni yang bertujuan mendapatkan banyak informasi dari para lulusan/alumni untuk meningkatkan kualitas lulusan. Pelacakan informasi alumni yang dapat dijadikan sebagai input dan evaluasi bagi perbaikan pembelajaran serta kompetensi lulusannya. Informasi berupa kegiatan/aktivitas para lulusan/alumni setelah menempuh pendidikan pada UMKO, baik dalam masa tunggu atapun telah memilki kegiatan didunia kerja. Tracer study yang terkomputerisasi secara online dalam pelacakan para alumni dapat dengan mudah mendata alumni yang dingikan dapat langsung diberikan oleh lulusan/alumni, dimana sistem yang dibangun dapat mendata lulusan/alumni berdasarkan tahun kelulusan, bidang kometensi, jumlah lulusan, profil pekerjaan yang digambarkan dalam bentuk persentase, grafik atau diagram. Pengembangan perangkat lunak menggunakan metode OOSE dengan tahapan : (1) Requirement Engineering (Rekayasa persyaratan), (2) Desain Object Oriented, (3) Implementasi atau Coding, (4) Testin. Proses pelacakan dengan menggunakan sistem yang terintegrasi ini mampu menghubungkan dan menyimpan seluruh informasi lulusan dalam 1 (satu) media, sehingga mampu memberikan inforamsi kepada siapapun yang membutuhkannya. Selain itu data yang diinput pun langsung oleh para alumni sehingga tingkat data lebih akurat, sehingga dapat memberikan masukan kepada UMKO meningkatkan kualitas lulusan.
\end{abstract}

Kata Kunci : Tracer Study, Alumni, OOSE, Pelacakan 


\section{PENDAHULUAN}

Tracer Study dilaksanakan untuk mendapatkan banyak informasi dari alumn iyang bertujuan untuk peningkatkan kualitas pendidikan, seperti perbaikan kurikulum dan modul praktikum. Universitas Muhammadiyah Kotabumi (UMKO) adalah perguruan tinggi yang berlokasi di Kabupaten Lampung Utara, saat ini, UMKO mengelola sebelas program studi dan empat fakultas, adapun fakultas yang dimiliki UMKO yaitu 1) Fakultas Keguruan dan Ilmu Pendidikan, 2) Fakultas hukum dan Ilmu Sosial, 3) Fakultas Pertanian dan Peternakan, 4) Fakultas Teknik dan Komputer.

Pelacakan alumni pada Perguruan Tinggi di Indonesia saat ini telah berjalan, informasi yang didapat dari setiap alumni dapat dijadikan sebagai input dan evaluasi bagi perbaikan pembelajaran serta kompetensi lulusannya. Selain itu melacak kegiatan/aktivitas para lulusan/alumni setelah menempuh pendidikan pada perguruan tinggi, baik dalam masa tunggu atapun telah memilki kegiatan didunia kerja

UMKO belum memilki sebuah sistem Tracer study yang terkomputerisasi secara online dalam pelacakan para alumni Tracer study yang terkomputerisasi secara online dalam pelacakan para alumni dapat dengan mudah mendata alumni yang dingikan dapat langsung terjawab / terisis oleh para alumni, dimana sistem yang dibangun dapat mendata waktu tunggu memeperoleh pekerjaan, kesesuaian pekerjaan dengan keahlian yang dimiliki, gaji yang didapat dan lain sebagainya. Penulis ingin Menerapkan Sistem Inforamsi Tracer Study bagi para lulusan/alumni Universitas Muhammadiyah Kotabumi, adapun perangkat lunak yang akan dibuat diantaranya :

1. Sistem dibangun diperuntukan bagi alumni UMKO

2. Sisten Informasi Berbasis Web

3. Adanya hasil laporan Tracer Study

Sistem terpusat bagi Pusat Karir, Kemahasiswaan dan Alumni (PKKA), Wakil Rektor III serta lulusan/alumni dalam berbagi dan memperoleh informasi lulusan yang butuhkan, bahkan masukan berupa saran dan kritik dari para lulusan untuk meningkatkan kualitas UMKO.

\section{METODE}

A. Bagan alur proses penelitian

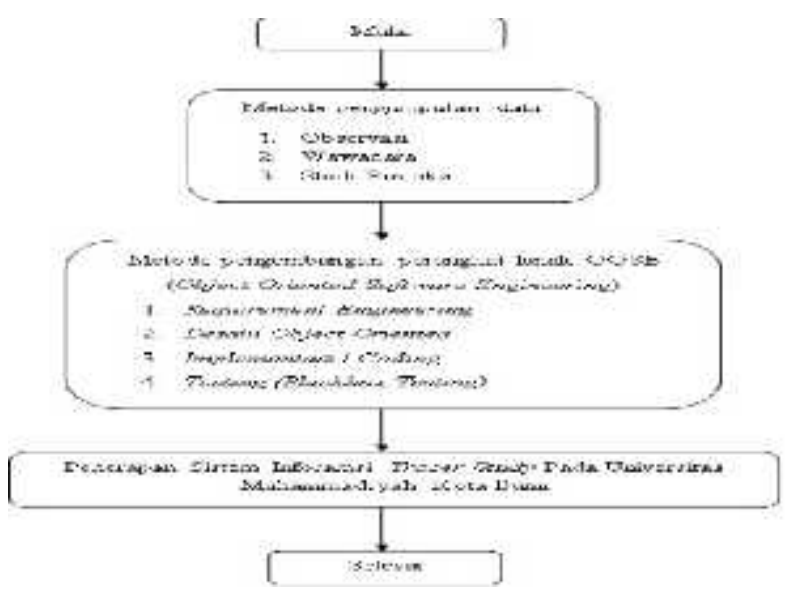

Gambar 1. Kerangka Pikir 


\section{B. Metode Penembangan Sistem}

Dalam mengembangan perangkat lunak pada penelitian ini peniliti menggunakan metode Object Oriented Software Engineering (OOSE). Tahapan pada OOSE adalah : (1) Requirement Engineering (Rekayasa persyaratan), (2) Desain Object Oriented, (3) Implementasi atau Coding, (4) Testing

\section{Identifikasi Masalah}

Penulis terlebih dahulu membuat diagram Analisis Sistem yang sudah ada

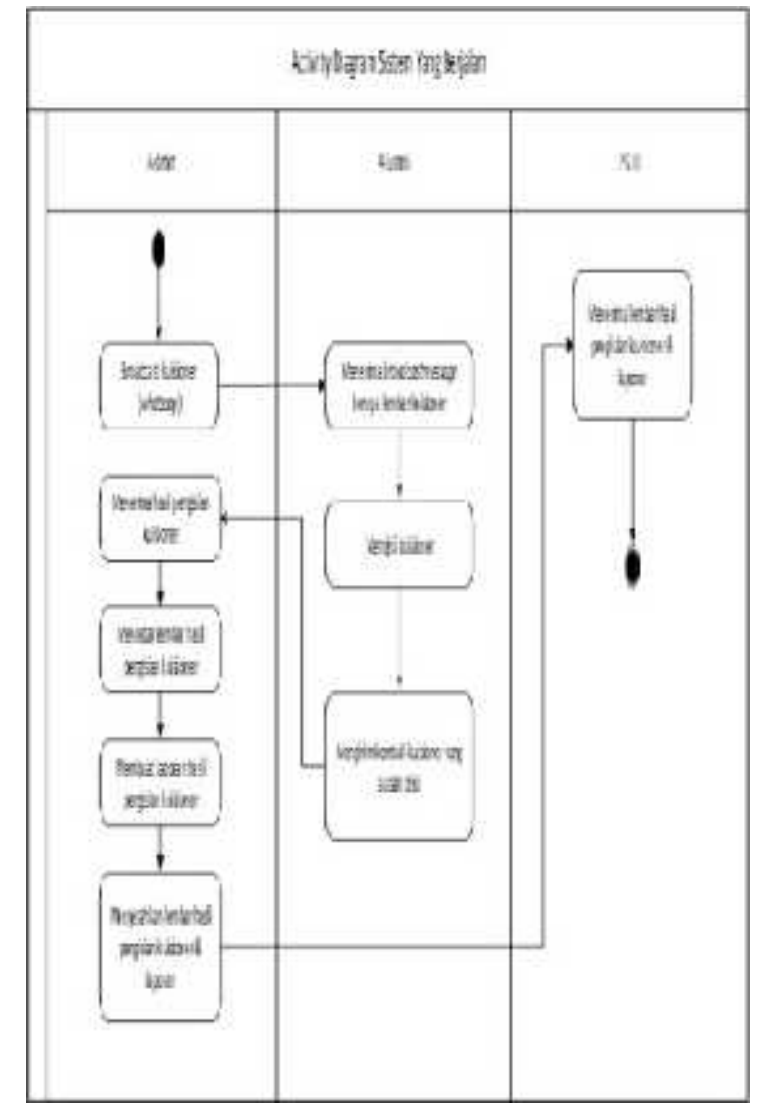

Gambar 2. Alur Sistem pada UMKO

a. Kelemahan Sistem Yang Diajukan
Terdapat beberapa kelemahan pada Sistem yang bejalan, adapun kelemahan tersebut sebagai berikut :

1. Penyebaran kuisioner melalui fasilitas SMS, Whatsapp untuk para lulusan

2. Pengelompokkan dalam penecekan data alumni membutuhkan waktu yang lama

3. Belum adanya penggunaan DBMS dalam penyimpanan data

Analisis Kebutuhan Hardware dan Software 1. Analisis Kebutuhan Non Fungsional

a. Analisis Kebutuhan Perangkat Keras (Hardware)

Adapun spesifikasinya adalah sebagai berikut :

a) Komputer/Laptop dengan spesifikasi yang digunakan Intel(R) Core (TM) i3-5005U CPU@2.00 GHz, 2.00 GHz, Ram 4 .00 GB.

b) Printer Epson L210

c) Hardisk $500 \mathrm{~Gb}$

b. Analisis Kebutuhan Perangkat Lunak (software)

Adapun spesifikasi software yang dibutuhkan sistem adalah :
a) Sistem Operasi Windows 7
b) PHP Designer 8
c) $\mathrm{CSS}++$
d) Microsoft Word 2010
e) DBMS MySql
f) Microsoft Visio 2013
g) SMTP Gmail 

h) Notepad ++
i) Хатрp
j) Web Browser

c. Analisis Kebutuhan Pengguna

Kebutuhan pengguna aplikasi adalah sebagai berikut :

a) Karyawan PPKA dan Wakil Rektor III

b) Alumni

\section{Metode Pengumpulan Data}

a. Observasi

Mengamati dan menganalisa bagaimana proses pelacakan alumni, penyebaran kuisoner, pengumpulan data alumni dan pengelompokkan data alumni pada Universitas Muhammadiyah Kotabumi (UMKO)

\section{b. Wawancara}

Wawancara dengan narasumber terkait. Narasumber yang dijadikan subjek wawancara yaitu Kepala Pusat Karir, Kemahasiswaan dan Alumni (PKKA), Wakil Rektor III, dan beberapa alumni.

c. Studi Pustaka

Pengumpulan refrensi terhadap jurnal-jurnal terdahulu kemudian mengutip dan membuat catatan yang bersumber pada bahan-bahan pustaka yang mendukung dan berkaitan dengan penelitian ini khususnya dalam Sistem Tracer Study yang berhubungan dengan masalah yang akan dibahas dalam penelitian ini.

\section{HASIL DAN PEMBAHASAN}

\section{Requirment Engineering}

Alur usulan yang dibangun telah menyesuaikan dengan hasil pengumpulan data dari para pengguna.

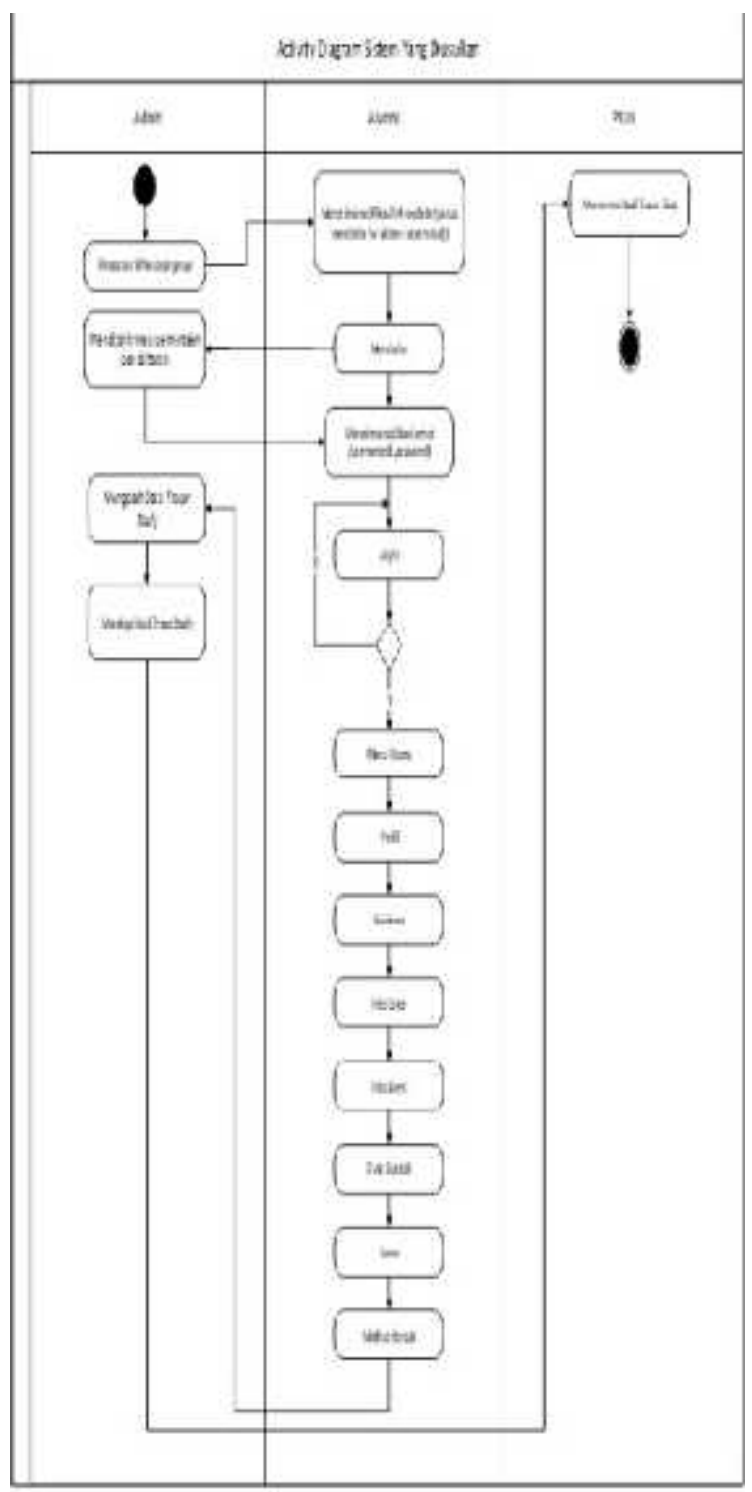

Gambar 3. Alur Usulan dalam Diagram Activity 
Desain Sistem

\section{Use Case Diagram}

Rancangan sistem yang terdiri dari aktor/pengguna, batasan, sub sistemsubsistem serta hubungan antara sub sistemsub sistem tersebut.

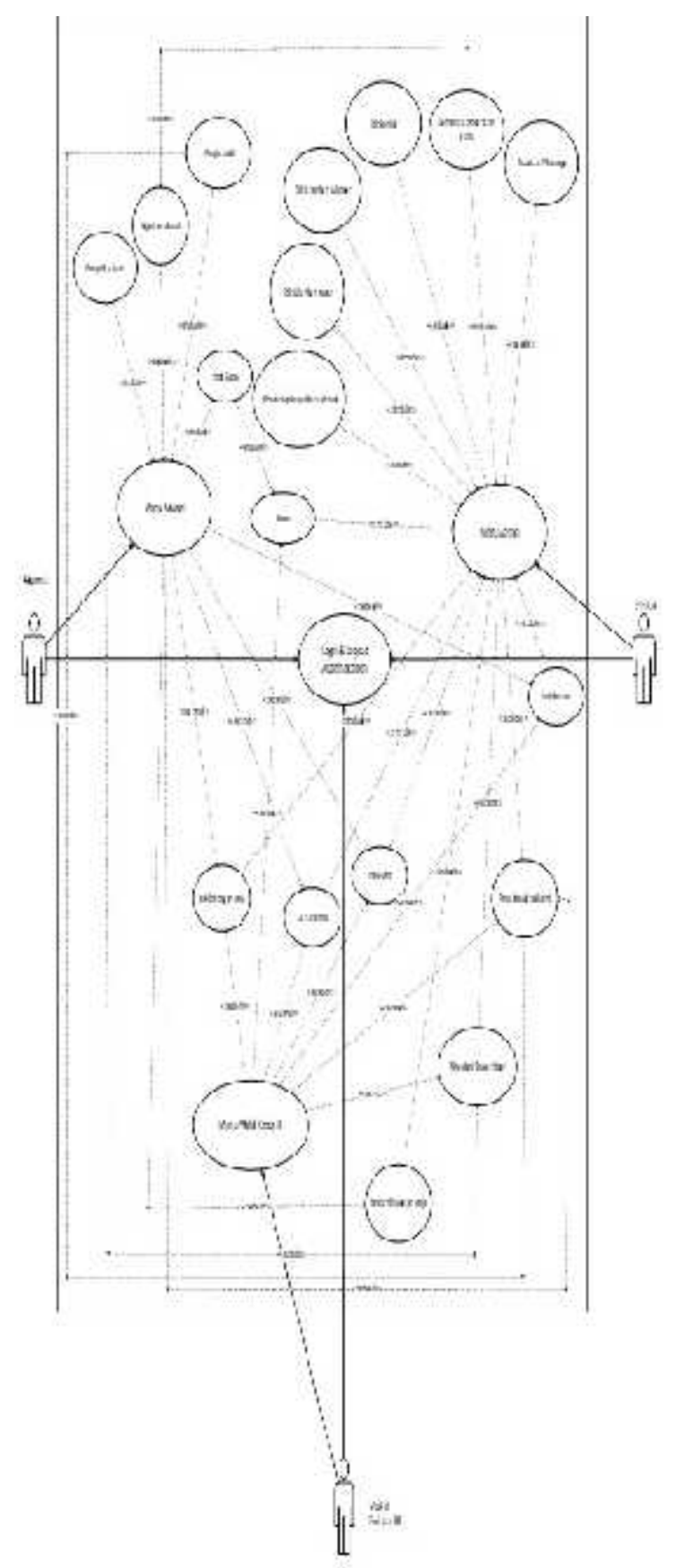

Gambar 4. Penerapan Sistem Tracer Study Pada UMKO

\section{Class Diagram}

Model/rancangan dari kelas-kelas dan objek yang terhubung antara satu dengan yang lain.

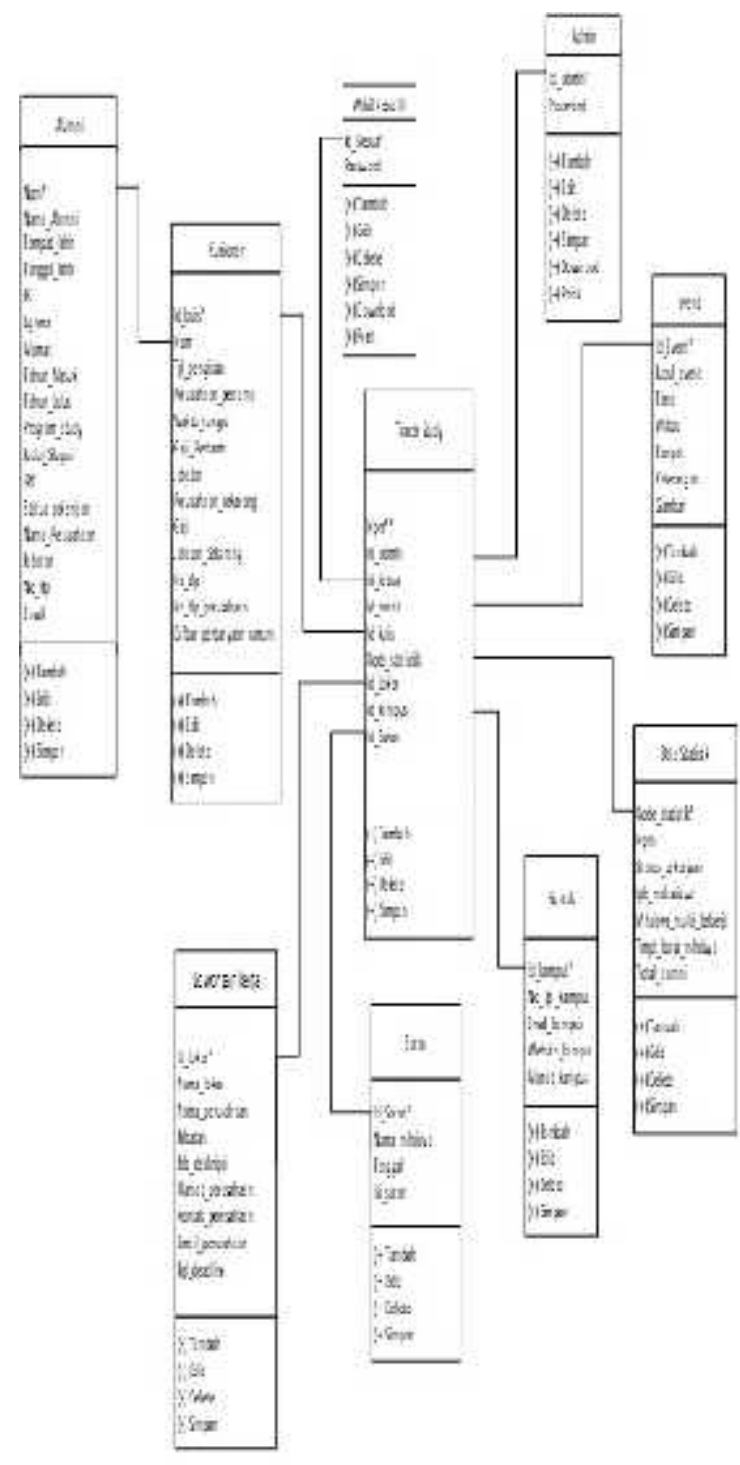

Gambar 5. Class Diagram

\section{Activity Diagram}

Suatu alur proses dalam suatu sub sistem dengan pengguna, yang terdiri dari aktivitas Input, Process dan Output. 


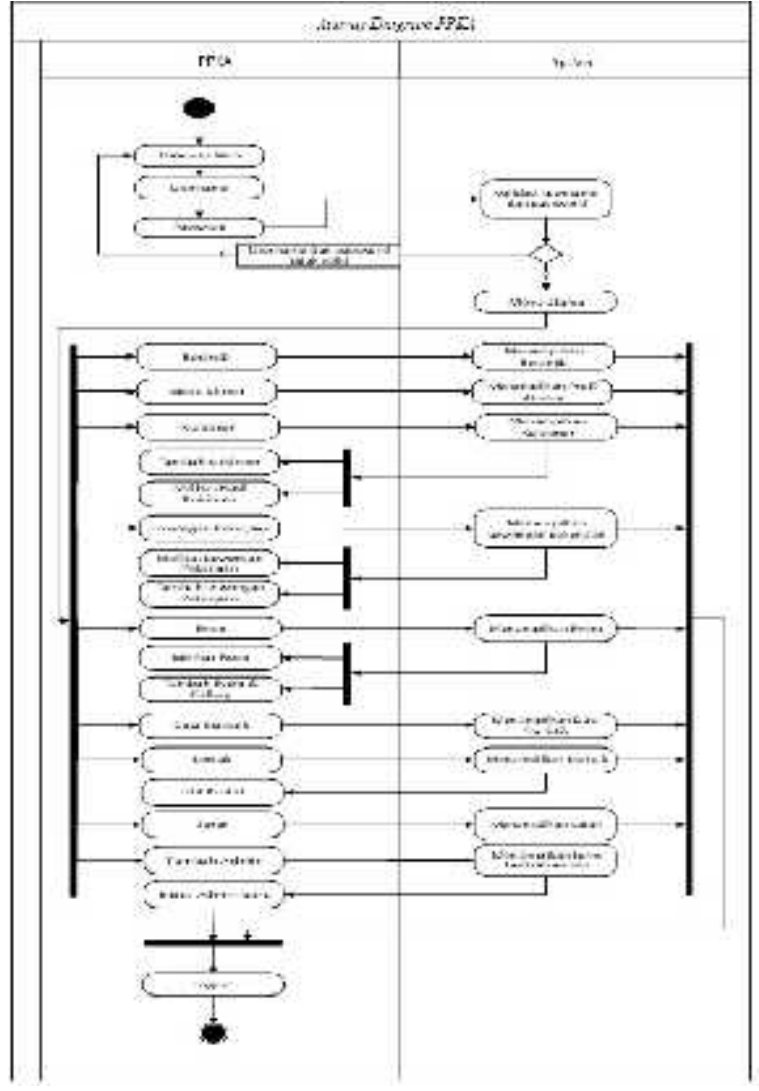

Gambar 6. Alur Sub Sistem oleh PPKA

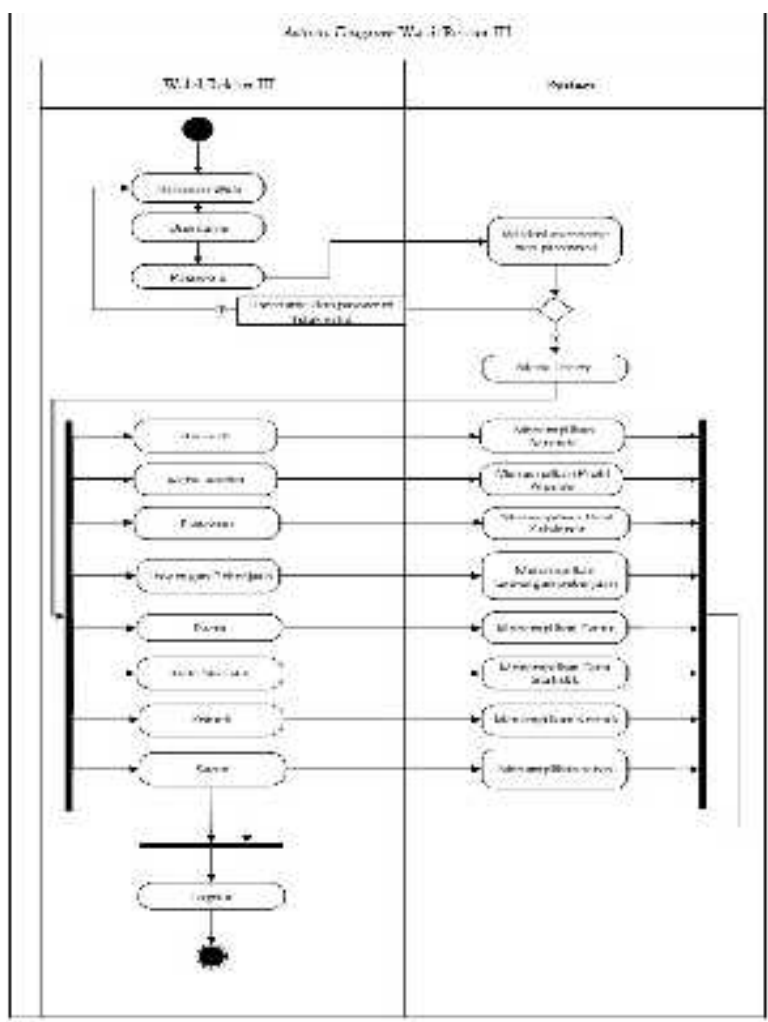

Gambar 7. Alur Sistem oleh Wakil Rektor III

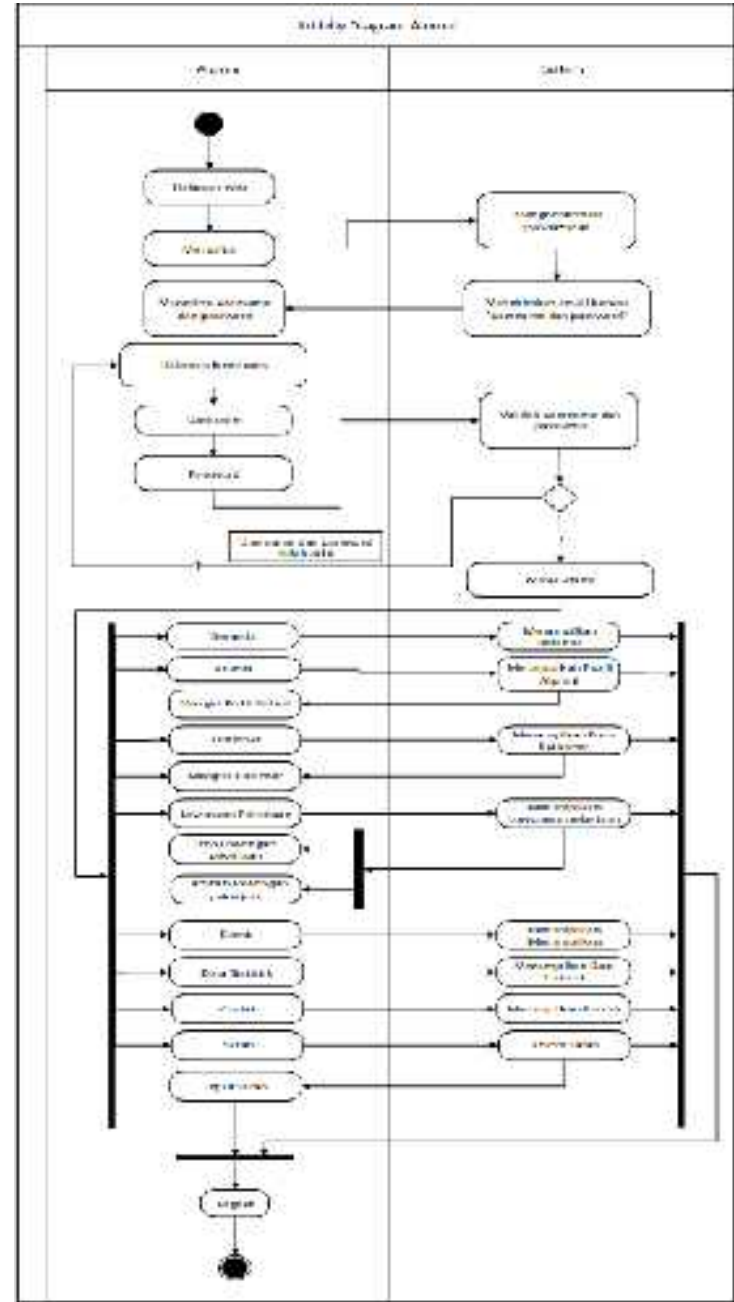

Gambar 8. Alur Sistem oleh Alumni

\section{Implementasi Sistem}

Tahapan ini merupakan bentuk action/implementasi pada sistem yang telah dirancang, dari proses penyebaran kuisoner melalui Email, pengisian kuisoner oleh lulusan/alumni, perekapan data lulusan/alumni sampai dengan informasi yang dapat diberikan oleh para stakeholder.

1. Tampilan Notifikasi

Lulusan/Alumni akan mendapatkan notifikasi/pemebritahuan melalui email yang telah terdaftar. 


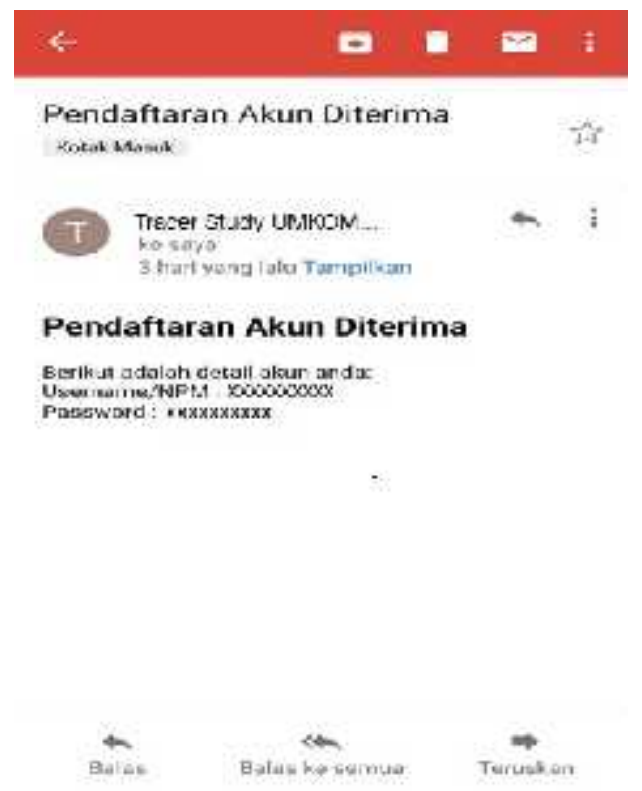

Gambar 9. Tampilan Notifikasi Pendaftaran

2. Tampilan Menu Utama

Menu ini terdiri dari beberapa sub menu, beranda, alumni. kuisioner, lowongan kerja, data statistik, event.

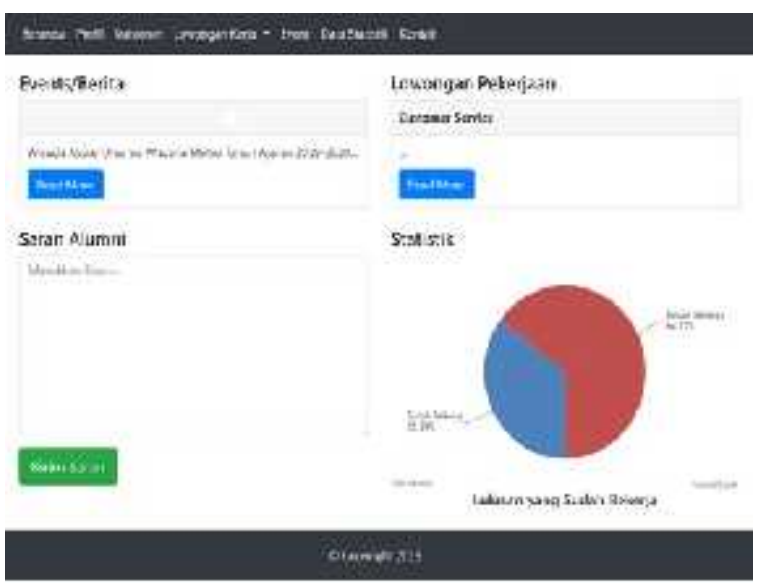

Gambar 10. Tampilan Menu Utama

3. Tampilan Menu Event

Halaman ini berisi informasi tentang kegiatan/acara dilingkungan Universitas Muhammadiyah Kotabumi

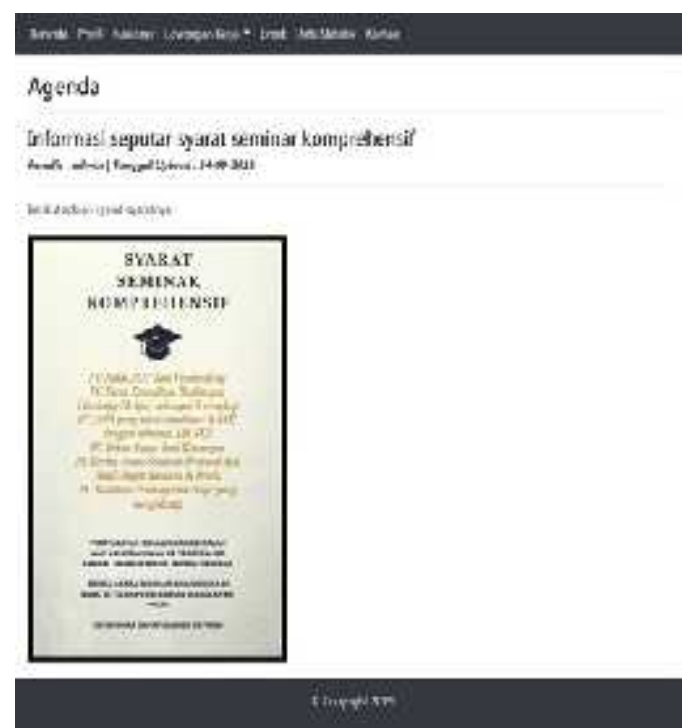

Gambar 11. Tampilan Menu Event

4. Tampilan Menu Hasil Kuisioner

Halaman menu ini menampilkan form hasil isian yang sudah diisi oleh para lulusan/alumni

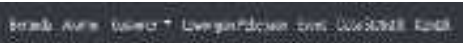

Hasl Kuisioner

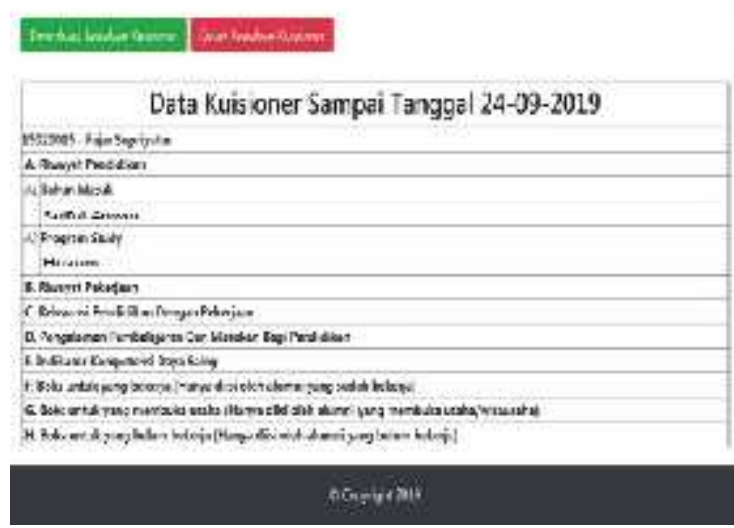

Gambar 12. Tampilan Informasi Hasil Kuisioner

5. Tampilan Informasi Data Statistik. Halaman ini memberikan informasi tentang data alumni yang telah dikelompokkan dan ditunjukan dalam bentuk persentase, grafik, diagram. 


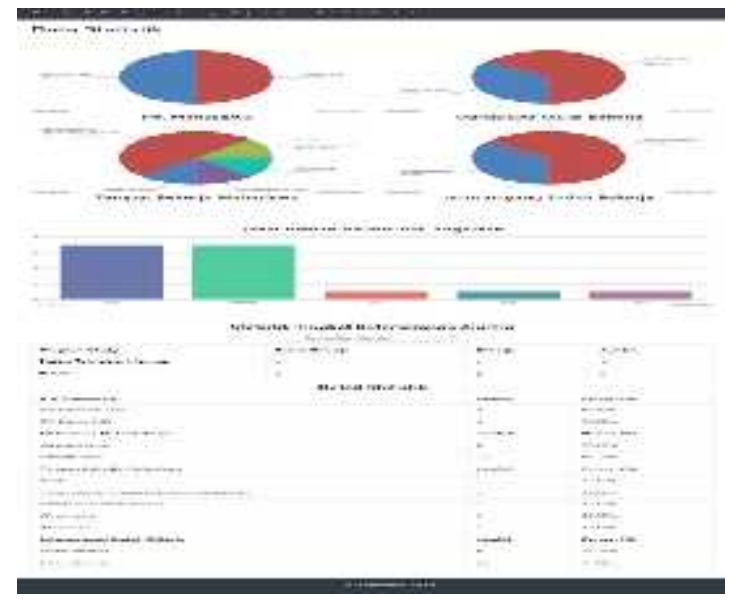

Gambar 13. Tampilan Informasi Data Statistik
5. Pengujian Sistem

a. Black box testing menu kuisioner alumni Fungsi : Untuk alumni mengisi Menu kuisioner yang tersedia

Deskripsi : Lulusan/alumni mengisi data diri terlebih, kemudian mengisi sub kuisioner yang tersedia. Hasil pengujian pada menu kuisioner alumni dapat dilihat pada tabel dibawah ini

Tabe. ]. Yenguian Menu Kumsioner

\begin{tabular}{|c|c|c|c|}
\hline Tahapan & Test Input & $\begin{array}{cc}\text { Respon Sistem } & \text { Hasil Respon } \\
\text { Sistem }\end{array}$ & Kesimpulan \\
\hline 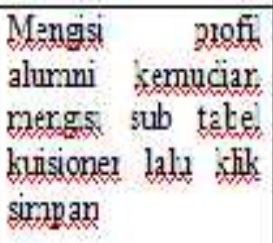 & $\begin{array}{|lr|}\text { Input } & \text { profi } \\
\text { kemudian } & \text { mergs } \\
\text { kijionex } & \end{array}$ & $\begin{array}{ll}\text { meramrilkan } & \text { "kjisioner } \\
\text { rotifikasi } & \text { berhast dismpan } \\
\text { "kuisioner berhasil } & \\
\text { cisimpan" } & \end{array}$ & Sesuis \\
\hline 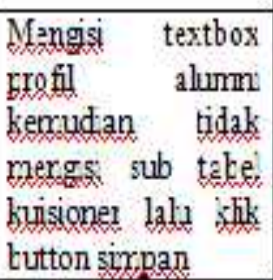 & \begin{tabular}{|l|} 
Input profil \\
kemudian \\
mengosongisar, sub \\
tajelkuisioner
\end{tabular} & $\begin{array}{l}\text { meramrilkan } \\
\text { rotificas "please fill out } \\
\text { fill out this field" }\end{array}$ & Sesuai \\
\hline $\begin{array}{l}\text { Tidakmergsi } 210 f i \\
\text { alummi kernuciar, } \\
\text { tddak mengigi sul } \\
\text { tabel kuisioner all } \\
\text { klik simpan }\end{array}$ & $\begin{array}{l}\text { projil can sub tabe } \\
\text { kuisione: } \\
\text { dikosongkan }\end{array}$ & $\begin{array}{l}\text { meramrilkan "piease fill out } \\
\text { rotifikas "please thisfield" } \\
\text { fill out this field" }\end{array}$ & Sesuai \\
\hline
\end{tabular}


b. Black box testing menu data statistik

Fungsi : Untuk menampilkan grafik atau presentase alumni berdasarkan pengelompokan pekerjaan, bidang lulusan, serta jumlah alumni

Deskripsi : Alumni, PPKA dan Wakil Rektor III memilih menu data Statistik

Tabel 2. Pengujian Menu Data Statistik

\begin{tabular}{|l|l|l|c|c|}
\hline $\begin{array}{c}\text { Tahapa } \\
\text { n }\end{array}$ & $\begin{array}{c}\text { Test } \\
\text { Input }\end{array}$ & $\begin{array}{l}\text { Respon } \\
\text { Sistem }\end{array}$ & $\begin{array}{c}\text { Hasil } \\
\text { Respon } \\
\text { Sistem }\end{array}$ & $\begin{array}{c}\text { Kesi } \\
\text { mpul } \\
\text { an }\end{array}$ \\
\hline $\begin{array}{l}\text { Mengkli } \\
\text { k menu } \\
\text { data } \\
\text { statistik }\end{array}$ & $\begin{array}{l}\text { Klik } \\
\text { menu } \\
\text { data } \\
\text { statisti } \\
\mathrm{k}\end{array}$ & $\begin{array}{l}\text { Akan } \\
\text { tampil } \\
\text { info data } \\
\text { statistik }\end{array}$ & $\begin{array}{l}\text { Menam } \\
\text { pilkan } \\
\text { data } \\
\text { statistik }\end{array}$ & $\begin{array}{c}\text { Sesua } \\
\text { i }\end{array}$ \\
\hline
\end{tabular}

\section{SIMPULAN}

1. Kesimpulan

Proses pelacakan dengan menggunakan sistem yang terintegrasi ini mampu menghubungkan dan menyimpan seluruh informasi lulusan dalam 1 (satu) media, sehingga mampu memberikan informasi kepada stakeholder dilingkungan UMKO

Selain itu data yang diinput pun langsung oleh para alumni sehingga tingkat data lebih akurat dan sesuai dengan profil lulusan/alumni, sehingga dapat memberikan masukan kepada UMKO meningkatkan kualitas lulusan yang berikutnya.

2. Saran

Perlu sosialisasi untuk merangkul keseluruhan para alumni dengan memanfaatkan media lain untuk meningkatkan para alumni agar dapat memberikan inforamsi tentang kualitas dan saran yang lebih baik, selalu memback-up secara berkala untuk menjaga hal-hal yang tidak diingikan.

\section{DAFTAR PUSTAKA}

Ahmad Nasuha, K. S. (2016). Analisis Dan Perancangan Sistem Informasi Alumni (Tracer Study) Berbasis Web Pada Iain Sulthan Thaha Saifuddin Jambi. Stikom Dinamikabangsa, Jambi., Vol 1 No 1.

Ependi, U. (2014). Implementasi Metode Ooad Pada Perancangan Kamus Istilah Akuntansi Berbasis Mobile. Program Studi Teknik Informasi Fakultas Ilmu Komputer Universitas Bina Darma.

Ernes Cahyo Nugroho, I. N. (2018). Sistem Pusat Karir Dan Tracer Study Perguruan Tinggi. Stmik Aub Surakarta., Volume 7 No 1.

Lukman Hakim, M. O. (2017). Perancangan Sistem Tracer Alumni Pada Stmik Musi Rawas Berbasis Web Mobile. Stimk Musi Waras Lubuklinggau, Vol 2 No 2. 
Putri, S. E. (2017). Sistem Informasi Tracer Study Alumni Pada Stmik Gici Batam Berbasis Web. Stmik Gici Batam.

Vidila Rosalina, M. N. (2014). Rancang Bangun Customer Relationship Management (Crm) Pada Perusahaan Petrokimia Menggunakan Object Oriented Analysis And Design (Ooad). Program Studi Teknik Informatika, Universitas Serang Raya 